\title{
Association Between Plasma $\beta$-endorphin and WOMAC Score in Female Patients with Knee Osteoarthritis
}

\author{
Hori Hariyanto ${ }^{1 *}$, John Butarbutar ${ }^{2}$, Gatot Lawrence ${ }^{3}$, FX Budhianto Suhadi ${ }^{4}$, Andi Husni Tanra ${ }^{5}$
}

\author{
'Department of Anesthesiology, Medical Faculty of Pelita Harapan University, \\ Jln. Boulevard Jend. Sudirman Lippo Karawaci - Tangerang, Indonesia \\ ${ }^{2}$ Deparment of Orthopedics, Medical Faculty of Pelita Harapan University, \\ JIn. Boulevard Jend. Sudirman Lippo Karawaci - Tangerang, Indonesia \\ ${ }^{3}$ Department of Pathology, Medical Faculty of Hasanuddin University, \\ Jl. Perintis Kemerdekaan Km.10. Indonesia Makasar, Indonesia \\ ${ }^{4}$ Department of Clinical Pathology, Medical Faculty of Pelita Harapan University, \\ JIn. Boulevard Jend. Sudirman Lippo Karawaci - Tangerang, Indonesia \\ ${ }^{5}$ Department of Anesthesiology, Medical Faculty of Hasanuddin University, \\ Jl. Perintis Kemerdekaan Km.10. Indonesia Makasar, Indonesia \\ *Correspondence to: horimd@yahoo.com
}

\section{Abstract}

B

ACKGROUND: $\beta$-endorphin plays a role in the descending pain control in the central nervous system. Central sensitization may be involved in the generating and maintenance of osteoarthritis $(\mathrm{OA})$ pain. However, the correlation between $\beta$-endorphin and pain severity in OA has shown conflicting results. The aim of this study was to investigate the association between plasma $\beta$-endorphin and the severity of the disease.

METHODS: This study was an observational crosssectional study carried out on 60 female subjects with knee OA who fulfilled the inclusion criteria. Plasma $\beta$-endorphin was measured by a commercial enzymelinked immunosorbent assay (ELISA) kit. Osteoarthritis knees were classified by the Kellgren-Lawrence (KL) grading (1-4) criteria. The WOMAC (Western Ontario McMaster University Osteoarthritis) scoring method was used to assess self-reported physical function, pain, and stiffness.

\section{Abstrak}

$\tau$

ATAR BELAKANG: $\beta$-endorphin mempunyai peranan yang sangat penting pada mekanisme terjadinya nyeri terutama pada jalur hambatan desending pada susunan syaraf pusat. Sensitisasi sentral mungkin menjadi salah satu faktor penyebab nyeri pada osteoartritis (OA), tetapi pada beberapa penelitian hubungan antara $\beta$-endorphin dan derajat skala nyeri pada OA tidak menunjukkan hasil yang konsisten. Tujuan dari penelitian ini adalah melihat hubungan antara konsentrasi $\beta$-endorphin dalam plasma dan derajat nyeri pada OA sendi lutut.

METODA: Penelitian ini menggunakan desain studi potong-lintang. Sampel terdiri dari 60 wanita dengan OA sendi lutut yang memenuhi criteria inklusi. Konsentrasi plasma $\beta$-endorphin diukur dengan enzyme-linked immunosorbent assay (ELISA) kit. Derajat nyeri diukur dengan skor Western Ontario McMaster University Osteoarthritis (WOMAC). 
RESULTS: The mean of the participants' ages was 58 years old, ranging from 42 to 83 years. Overall, more than $70 \%$ of the participants were overweight with a mean of body mass index (BMI) of 27.59 . More than $54 \%$ of the participants were diagnosed of having KL grading 3 or 4. Plasma $\beta$-endorphin was correlated inversely with the WOMAC subscale of stiffness $(r=-0.3563, p=0.0065)$ and the WOMAC total score $(r=-0.286, p=0.0311)$, but no correlation was noted with the WOMAC subscale of pain and physical activity. There was no significant difference of the mean of plasma $\beta$-endorphin among the KL gradings.

CONCLUSION: Plasma $\beta$-endorphin is associated with better WOMAC total score and stiffness subscale, but not associated with $\mathrm{KL}$ grading of $\mathrm{OA}$.

KEYWORDS: Knee osteoarthritis, female, $\beta$-endorphin, WOMAC, Kellgren-Lawrence

Indones Biomed J 2012; 4 (2): 107-111
HASIL: Responden berusia rata-rata 58 tahun, dengan kisaran 42 tahun hingga 83 tahun. Lebih dari $70 \%$ responden mempunyai indeks massa tubuh (IMT) ratarata 27,59 . Lebih dari $54 \%$ responden mempunyai $\mathrm{KL}$ derajat 3 atau 4 . $\beta$-endorphin berbanding terbalik dengan tingkat WOMAC stiffness $(\mathrm{r}=-0,3563, \mathrm{p}=0,0065)$ dan WOMAC total score $(r=-0,286, p=0,0311)$ serta tidak ada hubungan yang signifikan dengan WOMAC pain maupun physical activity. Tidak ditemukan hubungan yang bermakna antara $\beta$-endorphin dan derajat KL.

KESIMPULAN: $\beta$-endorphin mempunyai hubungan yang signifikan dengan WOMAC total score dan WOMAC stiffness, tetapi belum menunjukkan perbedaan yang bermakna dengan KL.

KATA KUNCI: Osteoartritis, wanita, $\beta$-endorphin, WOMAC, Kellgren-Lawrence

Indones Biomed J 2012; 4 (2): 107-111

\section{Introduction}

Pain is the most prominent symptom of OA and is strongly associated with poorer quality of life $(1,2)$. The gate control theory of pain (3) postulates that loss of inhibitory interneurons (disinhibition) would result in central sensitization (4-6). Both preclinical and clinical evidence supports the hypothesis that central sensitization may be involved in the generating process of OA pain (5).

$\beta$-endorphin, which is synthesized and stored in the anterior pituitary gland from the precursor protein proopiomelanocortin (POMC) (7), plays a role in the descending pain control in the central nervous system. However, the correlation between plasma $\beta$-endorphin and pain severity either in acute or chronic pain has shown conflicting results (8-12).

The objective of the present study was to evaluate the correlation between plasma $\beta$-endorphin and the severity of disease of knees in female patients with OA.

\section{Methods}

\section{Study design}

This was an observational cross-sectional study on adult female patients with knee pain who visited Siloam Hospital Lippo Village for clinical consultation between December 2010 and January 2012. Knee OA was diagnosed based on the American College of Rheumatology criteria for OA (13). Patients with clinical evidence of rheumatic arthritis, trauma and other orthopedic diseases including spinal disorders with radicular pain were excluded. The present study was approved by the institutional ethical committee and informed consent was obtained from each of all participants.

\section{Patient population and clinical data collection}

Demographic data including age and BMI were collected. All patients underwent anteroposterior radiographs of the knee for OA grading. The pain severity was assessed using WOMAC score. 


\section{Laboratory study}

Blood samples were collected in EDTA containing tubes and then centrifuged. The resulting plasma was frozen in dry ice and stored at $-70^{\circ} \mathrm{C}$. After completing plasma samples of all participants, the plasma $\beta$-endorphin was analyzed with a commercial enzyme-linked immunosorbent assay (ELISA) kit (Peninsula Laboratories, LLC, San Carlos, CA 94070, USA).

\section{Grading of OA and pain evaluation}

Anteroposterior radiographs of the affected knees were made and the radiographs were scored by two examiners, namely an experienced orthopedic surgeon and a radiologist, using the Kellgren-Lawrence $(\mathrm{KL})$ grading scale as follows: grade 1: doubtful narrowing of joint space and possible osteophytic lipping; grade 2: definite osteophytes and possible narrowing of joint space; grade 3: moderate multiple osteophytes, definite narrowing of joint space, some sclerosis, and definite deformity of bone contour; grade 4: large osteophytes, marked narrowing joint space, severe sclerosis and definite deformity of bone contour (14). The functional status and pain level of the patients were evaluated using the Western Ontario McMaster University Osteoarthritis Index (WOMAC) scores (15). The index consists of 3 subscales, namely pain, stiffness and physical function. The correlations between the plasma levels of $\beta$-endorphin and $\mathrm{KL}$ as well as between $\beta$-endorphin and WOMAC were analyzed

\section{Statistical analysis}

The data were analyzed using statistical software STATA version 12 . Test of normality was done using KolmogorovSmirnov test to assess the distribution of the variables. Man-U-Whitney statistical analysis was used to determine the mean difference of $\beta$-endorphin among the KL grades. Spearman's correlation coefficient $\mathbf{r}$ was used to assess the relationship between $\beta$-endorphin and WOMAC. A p value $<0.05$ was considered significant. The inter-rater agreement of KL was analyzed using kappa test.

\section{Results}

The demographic, radiologic, and biological characteristics of the patients are shown in Table 1 . Only 57 samples of the plasma $\beta$-endorphin were able to be analyzed in this study. Overall more than $70 \%$ of the participants were overweight with a mean of body mass index (BMI) 27.59. More than $54 \%$ of the participants were diagnosed of having KL grade 3 or 4 . The data showed that the mean of $\beta$-endorphin was 1.68 (ranging from $0.003-10$, median 0.04 ) with a SD of 3.65 , which showed abnormality in the distribution. The kappa test of KL between two observers revealed the kappa value of 0.6253 and percent agreement was $76.67 \%$. The WOMAC subscale of stiffness score showed that the mean was 3.72 , ranging from 0 to 6 . The WOMAC subscale of pain showed a mean of 8.25 with SD of 2.44, and a subscale of function score mean of 28.18 with SD of 8.48. However, the total WOMAC scores had a mean of 40.15 which was different from the median of 46 . The standard deviation of the total WOMAC score was 10.69 , ranging from 11 to 57 .

Increase of WOMAC was associated with reduced level of $\beta$-endorphin, reaching significance in the WOMAC subscale of stiffness $(\mathrm{r}=-0.3563, \mathrm{p}=0.0065)$ and WOMAC total score $(\mathrm{r}=0.286, \mathrm{p}=0.0311)$. There was no relationship between $\beta$-endorphin and KL ( $\mathrm{r}=0.2155$, $\mathrm{p}=0.1074)$.

The mean of $\beta$-endorphin in KL-1\& 2 was 1.24 with SD of 3.24 and 1.44 with SD of 3.43, respectively. It was quite different with KL-4, which had a mean of 3.80 and SD of 5.12. However, the results of this analysis using ManU-Whitney showed there was no significant correlation between $\mathrm{KL}-4$ and $\mathrm{KL}-1 \& 2(\mathrm{p}=0,1541)$. 


\section{Table 1. Patients Demographics}

\begin{tabular}{lcccc}
\hline Variable & $\mathbf{n}$ & Mean \pm SD & Min/Max & Median \\
\hline Age (years) & 60 & $58.65 \pm 9.803$ & $42 / 83$ & 58 \\
BMI (kg/m2) & 60 & $27.59 \pm 4.54$ & $15.77 / 39.26$ & 27.16 \\
KL grading & $\mathrm{n}(\%)$ & & & \\
1 & $1(1.67)$ & & & \\
2 & $27(43.33)$ & & & \\
3 & $24(40.00)$ & & & \\
4 & $9(15.00)$ & $1.68 \pm 3.65$ & $0.003 / 10.00$ & 4 \\
$\beta$-endorphin & 57 & & & 9 \\
WOMAC & & $3.72 \pm 1.12$ & 0.6 & 32 \\
Stiffness score & 60 & $8.25 \pm 2.44$ & $2 / 12$ & 46 \\
Pain score & 60 & $28.18 \pm 8.48$ & $5 / 39$ & $11 / 57$ \\
Function score & 60 & $40.15 \pm 10.69$ & & \\
Total Score & 60 & & & \\
\end{tabular}

BMI: Body Mass Index, KL: Kellgren-Lawrence. WOMAC: Western Ontario McMaster University Osteoarthritis Index.

\section{Discussion}

The present study examined whether plasma $\beta$-endorphin was associated with the development of knee OA pain in female patients. This study demonstrated that $\beta$-endorphin had a weak significant negative correlation with the WOMAC total score and a moderately significant negative correlation with the WOMAC subscale of stiffness. The $\beta$-endorphin was not correlated with the KL grading and WOMAC subscales of pain and physical activity.

\section{Correlation between plasma $\beta$-endorphin and WOMAC score}

The degree of pain experienced in the surgical setting either during or after a procedure positively correlated with the plasma $\beta$-endorphin level but not with the cerebrospinal fluid (CSF) $\beta$-endorphin level (8). Another study also showed a negative correlation between intraoperative plasma $\beta$-endorphin concentration and postoperative pain severity $(9,10)$. In a study of OA of the knee, the plasma $\beta$-endorphin level was not related to the severity of pain either in the OA group or in the healthy subjects.
However, there are several reports regarding plasma $\beta$-endorphin in chronic pain. In a study of OA of the knee, the plasma $\beta$-endorphin level was not related to the severity of pain either in the OA group or in the healthy subjects. However, after acetaminophen administration, plasma $\beta$-endorphin was reduced in correlation with the pain relief (11). In the setting of chronic neuropathic diabetic pain in men, the study by Tsigos et al. showed no correlation between cerebrospinal fluid (CSF) level of $\beta$-endorphin and the severity of pain, but the level of POMC was 80 -fold higher (12). The result of the present study was comparable with that of the previous study which concluded that in intractable pain the level of $\beta$-endorphin in CSF was lower than in the control group (16). The negative correlation between plasma $\beta$-endorphin and pain severity in this study may be secondary to the abnormality of HPA axis in the setting of musculoskeletal diseases such as fibromyalgia and rheumatic arthritis $(17,18)$, and also some evidence revealed a significant contribution of deficient inhibitory descending influence in the development and maintenance of central sensitization in OA (19-22). 


\section{Correlation between plasma $\beta$-endorphin and $\mathrm{KL}$}

Some studies have reported a significant correlation between inflammatory cytokines with radiologic grading of bone destruction in OA patients (23-25). The concentration of $\beta$-endorphin in synovial fluid increased in the inflammatory autoimmune diseases as well as in the degenerative joint diseases such as osteoarthritis (26). However, the correlation between plasma $\beta$-endorphin and $\mathrm{KL}$ in female patients with knee OA has not been studied yet, and in this study no correlation was found between plasma $\beta$-endorphin and $\mathrm{KL}$ grading.

\section{Conclusion}

In conclusion, the present study has indicated an association between $\beta$-endorphin and the WOMAC subscale of stiffness and the WOMAC total score. However, there was no significant association with KL grading.

\section{Acknowledgement:}

We would like to express a very great appreciation to VeliSungono, M.S for his valuable and suggestions during the writing of this research work.

\section{References:}

1. Wieland HA, Michaelis M, Kirschbaum BJ, Rudolphi KA. Osteoarthritis [mdash] an untreatable disease? Nat Rev Drug Discov. 2005; 4(4): 331-44.

2. Creamer P. Osteoarthritis pain and its treatment. Current Opinion in Rheumatology. 2000; 12(5): 450-5.

3. Melzack R WP. Pain mechanism: a new theory. Science. 1965; 150: 971-9.

4. Ossipov MH, Dussor GO, Porreca F. Central modulation of pain. The Journal of Clinical Investigation. 2010; 120(11): 3779-87.

5. Latremoliere A, Woolf CJ. Central Sensitization: A Generator of Pain Hypersensitivity by Central Neural Plasticity. The journal of pain : official journal of the American Pain Society. 2009; 10(9): 895-926.

6. Yaksh TL. Behavioral and autonomic correlates of the tactile evoked allodynia produced by spinal glycine inhibition: effects of modulatory receptor systems and excitatory amino acid antagonists. Pain. 1989; 37(1): 111-23.

7. Guillemin R VT, Rossier J, Minick S. beta-Endorphin and adrenocorticotropin are selected concomitantly by the pituitary gland. Science. 1977; 197 (4311): 1367.

8. Matejec R, Ruwoldt R, Bödeker R-H, Hempelmann $G$, Teschemacher $H$. Release of $\beta$-Endorphin Immunoreactive Material Under Perioperative Conditions into Blood or Cerebrospinal Fluid: Significance for Postoperative Pain? Anesthesia \& Analgesia, 2003; 96(2): 481-6.

9. Hargreaves KM, Dionne RA, Mueller GP. Plasma BetaEndorphin-like Immunoreactivity, Pain and Anxiety Following Administration of Placebo in Oral Surgery Patients. Journal of Dental Research. 1983; 62(11):
1170-3.

10. Leonard TM, Klem SA, Asher MA, Rapoff MA, Leff RD. Relationship Between Pain Severity and Serum B-Endorphin Levels in Postoperative Patients. Pharmacotherapy: The Journal of Human Pharmacology and Drug Therapy. 1993; 13(4): 378-81.

11. Shen H, Sprott H, Aeschlimann A, Gay RE, Michel BA, Gay $\mathrm{S}$. Analgesic action of acetaminophen in symptomatic osteoarthritis of the knee. Rheumatology. 2006;45(6):76570.

12. Tsigos C, Gibson S, Crosby SR, White A, Young RJ. Cerebrospinal fluid levels of $\beta$ endorphin in painful and painless diabetic polyneuropathy. Journal of Diabetes and its Complications. 1995; 9(2): 92-6.

13. Altman R, Asch E, Bloch D, Bole G, Borenstein D, Brandt K, et al. Development of criteria for the classification and reporting of osteoarthritis. Classification of osteoarthritis of the knee. Diagnostic and Therapeutic Criteria Committee of the American Rheumatism Association. Arthritis Rheum. 1986; 29(8): 1039-49.

14. Kellgren J, Lawrence J. Radiological assessment of osteoarthrosis. Ann Rheum Dis. 1957; 16: 494 - 501.

15. Bellamy N, Buchanan W, Goldsmith C, Campbell J, Stitt L. Validation study of WOMAC: a health staus instrument for measuring clinically important patient relevant outcomes to antirheumatic drug therapy in patients with osteoarthritis of the hip or knee. J Rheumatol. 1988; 15: 1833 - 40.

16. Tsubokawa $T$, Yamamoto $T$, Katayama $\mathrm{Y}$, Hirayama $\mathrm{T}$, Sibuya $\mathrm{H}$. Thalamic relay nucleus stimulation for relief of intractable pain. Clinical results and $\beta$-endorphin immunoreactivity in the cerebrospinal fluid. Pain. 1984; 18(2): 115-26.

17. McBeth J, Chiu Y, Silman A, Ray D, Morriss R, Dickens C, et al. Hypothalamic-pituitary-adrenal stress axis function and the relationship with chronic widespread pain and its antecedents. Arthritis Research \& Therapy. 2005; 7(5): R992 - R1000.

18. Cutolo M FL, Minuto F. Hypothalamic-pituitary-adrenal axis impairment in the pathogenesis of rheumatoid arthritis and polymyalgia rheumatica. J Endocrinol Invet. 2002; 25(10 Suppl): 19-23.

19. Farrell M, Gibson S, McMeeken J, Helme R. Pain and hyperalgesia in osteoarthritis of the hands. J Rheumatol. 2000; 27: 441-7.

20. Hendiani JA, Westlund KN, Lawand N, Goel N, Lisse J, McNearney T. Mechanical sensation and pain thresholds in patients with chronic arthropathies. The journal of pain: official journal of the American Pain Society. 2003; 4(4): 203-11.

21. Imamura M, Imamura $S$, Kaziyama $H$, Targino R, Hsing W, de Souza L, et al. Impact of nervous system hyperalgesia on pain, disability, and quality of life in patients with knee osteoarthritis: a controlled analysis. Arthritis Rheum. 2008; 59: 1424 - 31.

22. Kidd B. Mechanisms of Pain in Osteoarthritis. HSS Jrnl. 2012; 8(1): 26-8.

23. Orita S, Koshi T, Mitsuka T, Miyagi M, Inoue G, Arai G, et al. Associations between proinflammatory cytokines in the synovial fluid and radiographic grading and pain-related scores in 47 consecutive patients with osteoarthritis of the knee. BMC Musculoskeletal Disorders. 2011; 12(1): 144.

24. Attur $\mathrm{M}$, Wang $\mathrm{H}-\mathrm{Y}$, Kraus VB, Bukowski JF, Aziz N, Krasnokutsky $\mathrm{S}$, et al. Radiographic severity of knee osteoarthritis is conditional on interleukin 1 receptor antagonist gene variations. Annals of the Rheumatic Diseases. 2010; 69(5): 856-61.

25. Long D, Blake S, Song X, Lark M, Loeser R. Human articular chondrocytes produce IL-7 and respond to IL-7 with increased production of matrix metalloproteinase-13. Arthritis Res Ther. 2008; 10: R23.

26. Toth K, Barna I, Nagy G, Wellinger K, Horvath G, Bender T. Synovial fluid $\beta$-endorphin level in avascular necrosis, rheumatoid arthritis, and osteoarthritis of the femoral head and knee. A controlled pilot study. Clinical Rheumatology. 2011; 30(4): 537-40. 